\title{
Historical analysis of leishmaniasis cases in the transamazonian region: from 2009 to 2019
}

\author{
Análise histórica dos casos de leishmaniose na região transamazônica: de 2009 a 2019
}

Análisis histórico de casos de leishmaniasis en la región transamazónica: de 2009 a 2019

Alexandre Apolo Silva Coelho ${ }^{1,3}$, Evellyn Vitória Sousa de Loureiro ${ }^{1}$, Andrey Caique Jorge da Silva ${ }^{1}$, Ana Beatriz Costa da Silva ${ }^{1}$, Helton Correa Alves ${ }^{1}$, Dalberto Lucianelli-Junior ${ }^{1,3}$, Antônio Vivaldo Pantoja ${ }^{1}$, Ozélia Sousa Santos ${ }^{1,3}$, Renan Rocha Granato ${ }^{1,3}$, Ademir Ferreira da Silva-Júnior ${ }^{1,3}$, Roberto Manoel do Nascimento ${ }^{2}$, Ronaldo Zucatelli Mendonça ${ }^{2}$, Rogério Valois Laurentino ${ }^{1 *}$, Fernanda Nogueira Valentin ${ }^{1,3 *}$.

\begin{abstract}
Objective: To determine the total number of notified cases, new cases and recurrence of American Tegumentary Leishmaniasis (ATL), to investigate the association between HIV coinfection and the presence of cutaneous lesion, as well to assess the concordance of two different laboratorial procedures: parasitological and histopathological in this region. Methods: This is a cross-sectional study. The research used data from the Information System for Notifiable Diseases, hence forth designated as SINAN (Sistema de Informação de Agravos de Notificação) that contained 6,183 cases of leishmaniasis in 9 municipalities. Results: As results, 5795 were of new cases and 351 recurrence cases. Among the cases 1,146 patients were tested for HIV, 16 presented coinfection from these 15 developed cutaneous lesion. In the overall studied population 5,690 subjects manifested cutaneous lesion. There was no agreement of the results regarding the quality of the parasitological and histopathological exams, demonstrating that they are poorly replicable $(p<0.005)$. Conclusion: The ATL is endemic in the transamazonian region posing as a major public health problem. All patients with leishmaniasis must be tested for HIV and health professionals must register on the notification form. The tests to diagnose leishmaniasis need to be more specific and sensitive.
\end{abstract}

Key words: Leishmania, HIV, Cutaneous lesion, Parasitological, Histopathological.

\section{RESUMO}

Objetivo: Determinar o número total de casos notificados, casos novos e recorrência da Leishmaniose Tegumentar Americana (LTA), investigar a associação entre a coinfecção pelo HIV e a presença de lesão cutânea, bem como avaliar a concordância de dois procedimentos laboratoriais distintos: parasitológico e histopatológico nessa região. Métodos: Este é um estudo transversal. A pesquisa utilizou dados do Sistema de Informação de Agravos de Notificação, doravante denominado SINAN, que continha 6.183 casos de leishmaniose em 9 municípios. Resultados: Como resultados, 5795 eram de casos novos e 351 casos de recorrência. Dos casos 1.146 pacientes testados para HIV, 16 apresentaram coinfecção, destes 15 desenvolveram lesão cutânea. Na população geral estudada 5.690 indivíduos manifestaram lesão cutânea. Não houve concordância dos resultados quanto à qualidade dos exames parasitológicos e histopatológicos, demonstrando que são pouco replicáveis $(p<0,005)$. Conclusão: $A$ ATL é endêmica na região transamazônica e constitui um importante problema de saúde pública. Todos os pacientes com leishmaniose devem ser testados para HIV e os profissionais de saúde devem se cadastrar na ficha de notificação. Os testes para diagnosticar a leishmaniose precisam ser mais específicos e sensíveis.

Palavras-chave: Leishmania, HIV, Lesão cutânea, Parasitológico, Histopatológico.

\footnotetext{
${ }^{1}$ Federal University of Pará, Altamira - PA. *E-mail: valois@ufpa.br, fervalentin@ufpa.br.

2 Butantan Institute, São Paulo - SP.

${ }^{3}$ Research Group on Health and Education in the Amazon (GEPSEA), Altamira - PA.
}

This study was partially funded by the Institutional Program for Scientific Initiation Scholarships (PIBIC) of the Federal University of Pará (UFPA), contemplating two scholarships (PR03664-2019). 


\section{RESUMEN}

Objetivo: Determinar el número total de casos reportados, casos nuevos y recurrencia de la leishmaniasis tegumentaria americana (ATL), investigar la asociación entre la coinfección por HIV y la presencia de una lesión cutánea, así como evaluar la concordancia de dos procedimientos de laboratorio diferentes: parasitológico e histopatológico en esta región. Métodos: Se trata de un estudio transversal. La investigación utilizó datos del Sistema de Información de Enfermedades Notificables, en adelante SINAN, que contenía 6.183 casos de leishmaniasis en 9 municipios. Resultados: Como resultado, 5.795 fueron casos nuevos y 351 casos de recurrencia. De los 1.146 pacientes sometidos a la prueba del HIV, 16 tenían coinfección, de los cuales 15 desarrollaron una lesión cutánea. En la población general estudiada, 5.690 individuos tenían una lesión cutánea. No hubo acuerdo en los resultados en cuanto a la calidad de los exámenes parasitológicos e histopatológicos, demostrando que son poco replicables $(p<0,005)$. Conclusion: El ATL es endémico en la región trans-amazónica y constituye un importante problema de salud pública. Todos los pacientes con leishmaniasis deben hacerse la prueba del HIV y los profesionales de la salud deben registrarse en el formulario de notificación. Las pruebas para diagnosticar la leishmaniasis deben ser más específicas y sensibles.

Palabras clave: Leishmania, HIV, Lesión cutánea, Parasitológica, Histopatológica.

\section{INTRODUCTION}

The American Tegumentary Leishmaniasis (ATL) is a non-contagious infectious disease caused by different species of protozoa of the genus Leishmania (L). In Brazil, especially in the Amazon Region, there are seven species which are the etiological agents of different clinical forms: subgenre Viannia $(V)$ e Leishmania (L): L. (V) braziliensis, L. (V.) guyanensis, L. (V.) lainsoni, L. (V.) naiffi, L. (V.) shawi e L. (V.) lindenbergi representative of the complex $L$. (V.) braziliensis; and $L$. (L.) amazonensis of $L$. Mexicana complex (LAINSON R, 1988). In the Amazon, the main vectors are insects called sandflies, that belong to the genre Lutzomia known popularly as straw mosquito, tatuquira, birigui and other synonyms (RANGEL EF e LAINSON R, 2003; DE OLIVEIRA GUERRA JA, et al., 2006).

The ATL is a major problem of public health in 85 countries, distributed in four continents (Americas, Europe, Africa and Asia), with annual registers of 0,7 to 1,3 million new cases (MINISTÉRIO DA SAÚDE, 2017). In Brazil transmission peaks are observed every five years, showing a tendency to increase the number of cases, since 1985, when the implementation of ATL surveillance and control actions in the country was solidified. From 1995 to 2014, there was an annual average of 25,763 new cases registered and an average detection rate of 14.7 cases / 100 thousand inhabitants, with a higher coefficient in 1995, when it reached 22.94 cases per 100 thousand inhabitants (MINISTÉRIO DA SAÚDE, 2017). Therefore, the disease represents a serious public health problem in the country, due to its high incidence and capacity to assume serious and lethal forms (MINISTÉRIO DA SAÚDE, 2007a).

Over the past fifteen years, an increase in cases of ATL has been reported in several states in the Amazon (MINISTÉRIO DA SAÚDE, 2007a). In the state of Pará, the disease has been spreading in several regions, in the period from 2008 to 2016, the number of cases of ATL in Pará corresponded to $16.5 \%$ of the 179,346 cases reported in Brazil, with the state having the highest number of notifications (ESTUMANO JC, et al., 2020).

The increase in the number of cases is a consequence of the continuous invasion of man in the wild, which interferes with the cycle of transmission between the hosts (wild animals) of Leishmania and its vectors. This epidemiological profile is related to activities such as deforestation, military training, ecotourism, construction of roads and hydroelectric dams (LAINSON R, 1988; MINISTÉRIO DA SAÚDE, 2007a).

In relation to the construction of Hydroelectric Plants (HP), the construction of large reservoirs is necessary and, consequently, deforestation and flooding of large areas, requiring the relocation of large contingents of people and wild animals (FERRETE JA, et al., 2004). The epidemiological profile of leishmaniasis has been modified over the years, as the disease outbreaks are not restricted only to nature, but also to peri-urban locations, in which the World Health Organization (WHO) (2016) confirms the likely adaptation of vectors due to environmental impact, as well as the insertion of domestic animals and intermediate hosts (TELES CBG, et al., 2013; ARAUJO-PEREIRA T, et al., 2014). 
Leishmaniasis is related to poverty and its consequences, given that it is considered a neglected disease that affects more than 500,000 people worldwide with high mortality rates (MARINHO DS, et al., 2015). In addition, it is considered an emerging disease or reemerging disease, because in the last two decades there has been an alarming increase in the incidence of cases of leishmaniasis in the world due to the increasing number of urban migration and climate change (GOTO H e LINDOSO JAL, 2010).

Tropical diseases considered "neglected", such as leishmaniasis, constitute a set of diseases prevalent in developing countries, which can affect the entire population, but which has had a greater impact on population groups in situations of social vulnerability, representing a serious barrier to development. socioeconomic status and improving the quality of life (VILLA TCS, 2009).

The clinical manifestations of ATL are characterized by skin and / or mucosal involvement. In patients with Leishmania-HIV co-infection, the spectrum is varied, skin lesions vary from papules to ulcers, with single or multiple lesions, the most common of which are ulcers. However, atypical lesions characterized by disseminated macules or papules can be found. In co-infected patients with severe immunosuppression, lesions can be found not only in exposed areas, but also in other unexposed areas, such as the genital region (MINISTÉRIO DA SAÚDE, 2015).

Regarding the diagnosis, there is no gold standard exam to identify ATL. However, the National Health Foundation (FUNASA) indicates the direct parasitological exam as the first choice exam, as it is fast and easy to perform (MINISTÉRIO DA SAÚDE, 2017). The tests must be chosen according to the time and evolution of the disease, level of complexity of the test and feasibility of application (GOMES CM, et al., 2014). Among the options for diagnosis, there are: serological tests, direct and histopathological examination, immunofluorescence, culture and Polymerase Chain Reactions (PCR) (ASSIS TSM, et al., 2015).

As for treatment, it is known that the drugs available on the market to treat American Tegumentary Leishmaniasis are quite low. For a long time, the WHO has recommended the use of pentavalent antimonials as therapy to treat it. However, in 2010, professionals specialized in leishmaniasis from WHO updated and modified the recommendations for leishmaniasis at a global level, as they have several side effects, such as weakness, headache, dizziness, insomnia, cardiotoxicity, pyrogenic shock, hepatitis and acute renal failure (MINISTÉRIO DA SAÚDE, 2017). In the treatment failure there are other second-line drugs that are used in the treatment, such as Amphotericin B or Pentamidine (MINISTÉRIO DA SAÚDE, 2017).

Given the above, the objective of the research were to determine the total number of reported cases, new cases and recurrence of ATL in the transamazon region between 2009 and 2019, to investigate the association between the presence of skin lesions and HIV co-infection, to analyze the agreement between the parasitological and histopathological exam, to investigate the association between the use of other drugs with cases of recurrence and the number of deaths. It is known that ATL is epidemic, however, there are few works with this theme, therefore, this study can contribute to identify possible deficiencies in patient care with ATL.

\section{METHODS}

It was a cross-sectional study that used the records contained in Notifiable Diseases Information System (SINAN) without the identification of human participants (MINISTÉRIO DA SAÚDE, 2007b). Therefore, the research is anonymous, with only numerical data and therefore does note need the approval of the ethics committee. The data collected were from 9 municipalities: Altamira, Anapu, Brasil Novo, Medicilândia, Pacajá, Porto de Moz, Senador José Porfírio, Uruará and Vitória do Xingu.

The information was obtained through an analytical form containing year, date of notification, municipality of notification, type of entry (frequency: total, new cases and recurrences) between January 2009 to May 2019, as variables such as the presence of skin lesion, co-infection by HIV, direct parasitological examination and histopathological examination, drugs used in the treatment, treatment failure and occurrence of death were associated with data from SINAN between January 2009 to December 2018.

Then, the data were tabulated and analyzed statistically using the BioEstat 5.0 program. The results were represented by graphs and tables. The variables were subjected to descriptive and analytical analysis. The values followed an abnormal distribution using non-parametric tests. Significant differences were considered when the $p$-value was less than 0.05 . 
To associate the variables skin lesion and co-infection with HIV, the logistic regression test was performed. To evaluate the positive and negative association between skin lesion and HIV co-infection, the Association $\mathrm{G}$ Test was used.

In the analysis of the positive and negative association between parasitological and histopathological exams in each year and for each municipality, the McNemar and Kappa tests were used. For positive and negative association between treatment failure and death and between treatment failure and recurrences in each year and for each municipality, Logistic Regression Test was used.

\section{RESULTS}

The frequency of total reported cases of American Tegumentary Leishmaniasis in the period from January 2009 to May 2019, corresponds to 6183 cases (Figure 1). The frequency of notification was higher in 2015, corresponding to 819 cases (13.2\%), followed by 2017 (745 - 12\%) and 2012 (692 - 11.1\%). The most frequent municipalities in Medicilândia (1523 - 24.6\%), Uruará (1437 - 23.2\%), Altamira (982 - 15.8\%), Pacajá (624 $10.3 \%$ ) and Anapu (607 - 9.8\%) stand out.

Figure 1 - Total frequency of notified cases and frequency of new ATL cases per municipality between 2009-2019 in the transamazonian region.

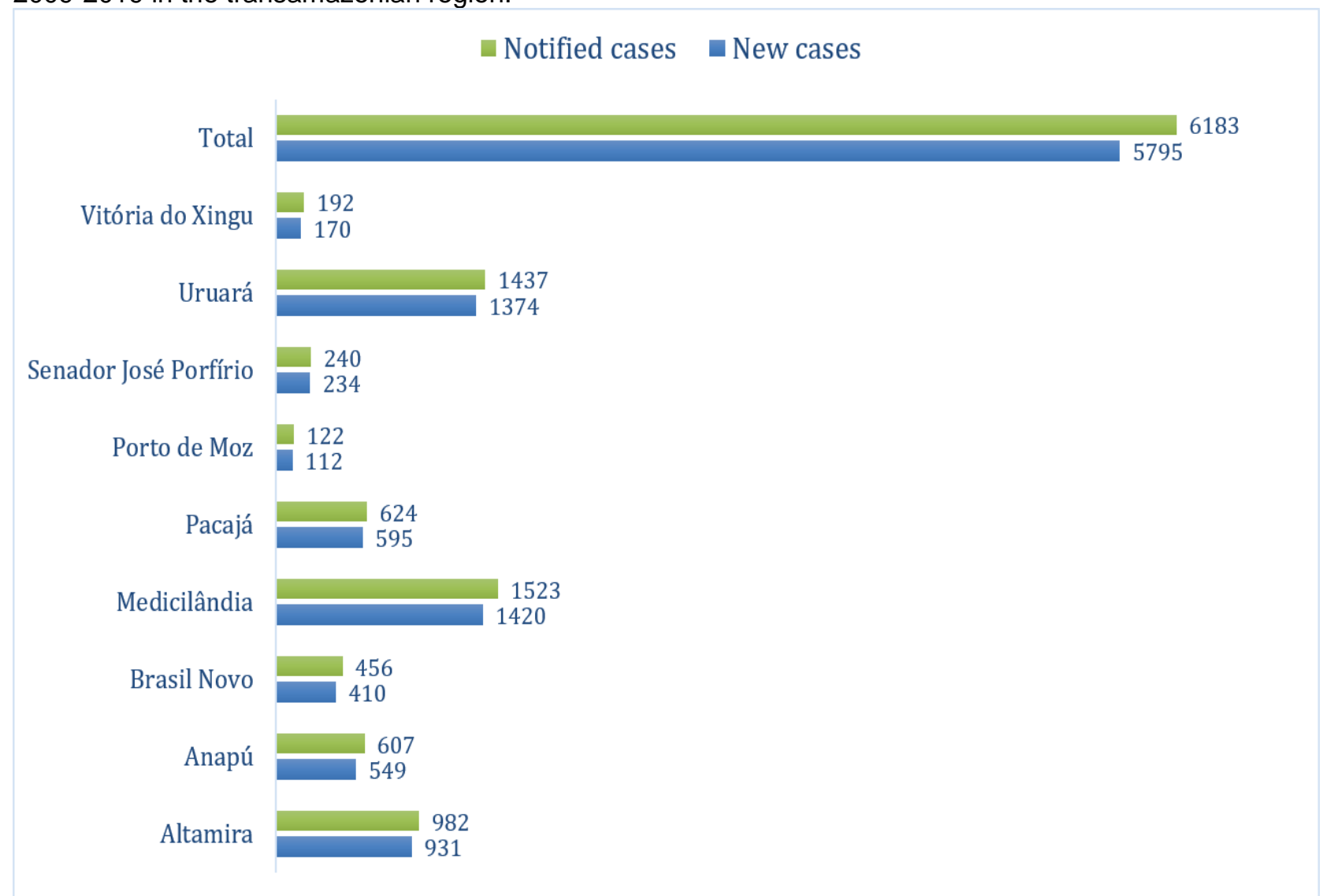

Source: Coelho AAS, et al., 2021.

When analyzing the frequency of new cases, 5795 cases were found. Of these, the majority occurred in 2015 (747 - 12.8\%), 2017 (691-11.9\%) and 2012 (678 - 11.6\%). Of this total, 4320 cases were concentrated in only 4 municipalities: Medicilândia (1420 - 32.8\%), Uruará (1374 - 31.8\%), Altamira (931 21.3\%) and Pacajá (595 - 13.7\%).

Regarding recurrence cases, in the same period, there were a total of 351 cases, with 69 cases (19.6\%) in 2015 , followed by $50(14.2 \%)$ and $47(13.3 \%)$ cases in 2017 and 2009 respectively. The municipality with the highest case of relapse was Medicilândia 102 cases (29\%). 
The male sex was the one with the highest number of reported cases in the analyzed period (2009 to 2019), corresponding to 4512 cases and the city of Medicilandia was the one with the highest number in both sexes. The most affected age group was between 31-59 years old, being Medilandia the city with the highest index, followed by Uruará and Altamira. The old people were the ones who had the lowest number of notifications in the analyzed period (Table 1).

Table 1 - Division by sex and age range groups of cases of ATL in the municipalities of the transamazonian region (2009 to 2019).

\begin{tabular}{ccccccc}
\hline \multirow{2}{*}{ Municipalities } & \multicolumn{3}{c}{ Sex } & \multicolumn{5}{c}{ Age range } \\
\cline { 2 - 7 } & women & male & $<\mathbf{1 8}$ & $\mathbf{1 8 - 3 0}$ & $\mathbf{3 1 - 5 9}$ & $>\mathbf{6 0}$ \\
\hline Altamira & 133 & 786 & 38 & 236 & 519 & 74 \\
Anapu & 158 & 426 & 90 & 172 & 278 & 33 \\
Brasil Novo & 109 & 333 & 49 & 118 & 246 & 25 \\
Medicilândia & 418 & 1034 & 215 & 500 & 612 & 99 \\
Pacajá & 105 & 499 & 30 & 193 & 320 & 48 \\
Porto de Moz & 12 & 105 & 12 & 31 & 53 & 21 \\
Senador José Porfírio & 40 & 163 & 20 & 59 & 100 & 15 \\
Uruará & 356 & 1007 & 176 & 411 & 617 & 94 \\
Vitória do Xingu & 20 & 159 & 9 & 48 & 102 & 12 \\
Total & $\mathbf{1 3 5 1}$ & $\mathbf{4 5 1 2}$ & $\mathbf{6 3 9}$ & $\mathbf{1 7 6 8}$ & $\mathbf{2 8 4 7}$ & $\mathbf{4 2 1}$ \\
\hline
\end{tabular}

Source: Coelho AAS, et al., 2021.

Of the 1,146 individuals surveyed regarding coinfection with HIV, 16 had coinfection, of these, 15 developed skin lesions and one did not. Of these 15, one was from the municipality of Altamira, five from Anapu, four from Medicilândia, one from Porto de Moz, three from Uruará and one from Vitória do Xingu. In 4649 cases, the option "ignored" was checked in that field of the form. The analysis of the total number of cases regarding the correlation between the presence of skin lesions and HIV co-infection was not significant (Table 2).

Table 2 - Association between the presence of cutaneous lesions and HIV co-infection in patients with ATL in the transamazonian region between January 2009 and December 2018.

\begin{tabular}{|c|c|c|c|c|}
\hline Municipalities & $\begin{array}{c}\text { Cutaneous lesion } \\
(+) \\
\text { HIV }(+)\end{array}$ & $\begin{array}{c}\begin{array}{c}\text { Cutaneous lesion } \\
(+) \\
\text { HIV }(-)\end{array} \\
\end{array}$ & $\begin{array}{c}\begin{array}{c}\text { Cutaneous lesion } \\
(-) \\
\text { HIV (+) }\end{array} \\
\end{array}$ & $\begin{array}{c}\text { Cutaneous } \\
\text { lesion (-) } \\
\text { HIV (-) }\end{array}$ \\
\hline Altamira & 1 & 172 & 1 & 11 \\
\hline Anapu & 5 & 21 & 0 & 1 \\
\hline Brasil Novo & 0 & 120 & 0 & 0 \\
\hline Medicilândia & 4 & 509 & 0 & 3 \\
\hline Pacajá & 0 & 21 & 0 & 1 \\
\hline Porto de Moz & 1 & 49 & 0 & 4 \\
\hline Senador José & 0 & 44 & 0 & 1 \\
\hline Uruará & 3 & 97 & 0 & 0 \\
\hline Vitória do Xingu & 1 & 62 & 0 & 5 \\
\hline TOTAL & 15 & 1095 & 1 & 26 \\
\hline
\end{tabular}

Source: Coelho AAS, et al., 2021.

Laboratory tests were analyzed for the agreement of the results in order to investigate their quality, the analysis of agreement by the McNemar tests showed no agreement between the tests performed $(p<0.003)$, the result was confirmed by the performance Kappa test $(p<0.015)$ demonstrating that the tests are poorly replicable (Table 3). 
Table 3 - Association between parasitological and histopathological exams in the population of the transamazonian region from 2009 to 2018.

\begin{tabular}{ccccc}
\hline \multirow{2}{*}{ Municipalities } & $\begin{array}{c}\text { Parasitological } \\
(+)\end{array}$ & $\begin{array}{c}\text { Parasitological } \\
(+)\end{array}$ & $\begin{array}{c}\text { Parasitological } \\
(-)\end{array}$ & $\begin{array}{c}\text { Parasitological } \\
(-)\end{array}$ \\
\cline { 2 - 5 } & $\begin{array}{c}\text { Histopathological } \\
(+)\end{array}$ & $\begin{array}{c}\text { Histopathological } \\
(-)\end{array}$ & $\begin{array}{c}\text { Histopathological } \\
(+)\end{array}$ & $\begin{array}{c}\text { Histopathological } \\
(-)\end{array}$ \\
\hline Altamira & 10 & 0 & 1 & 3 \\
Anapu & 11 & 6 & 0 & 0 \\
Brasil Novo & 5 & 5 & 1 & 1 \\
Medicilândia & 2 & 0 & 0 & 0 \\
Pacajá & 3 & 0 & 0 & 0 \\
Porto de Mós & 6 & 2 & 0 & 0 \\
Senador José & 18 & 1 & 0 & 0 \\
Porfírio & & & 0 & 0 \\
Uruará & 4 & 5 & 0 & 1 \\
Vitória do Xingu & 33 & 4 & $\mathbf{2}$ & $\mathbf{5}$ \\
TOTAL & $\mathbf{9 2}$ & $\mathbf{2 3}$ & & \\
\hline
\end{tabular}

Source: Coelho AAS, et al., 2021.

There was no significant correlation between the type of treatment used (drug: pentavalent antimonial) and (other drugs: amphotericin $b$, pentamidine) with leishmaniasis recurrence ( $p>0.05)$. The municipalities that presented the highest relationship between cases of relapse with the use of medications were Anapu and Medicilândia. The first municipality totaled 648 individuals, of which 110 account for the drug / relapse ratio and 6 the other drugs / relapse ratio. The second municipality, registered 1411 cases, in the drug / relapse ratio it had 90 cases and 51 in the other drugs / relapse ratio. However, it is not a significant number that can safely state that the cases of recurrence are related to the drugs used in the treatment.

When correlating the use of other drugs in the treatment failure with death, it was noticed that there was no statistical significance between these parameters, with $p>0.05$.

\section{DISCUSSION}

This study pointed out that between the period from 2009 to 2019, the year 2015 presented the highest frequency of cases reported by American Tegumentary Leishmaniasis. This is probably related to the construction of the Belo Monte Hydroelectric Plant, the largest genuinely Brazilian hydroelectric plant (VILELA $\mathrm{ML}$, et al., 2011). In 2011, the construction of the plant began, which led to a series of transformations, among which: flooding of an extensive area that affected fauna and flora; flooding of cities, small communities and agricultural areas, a consequence of the river barrier to form the reservoir, De Francesco A e Carneirom C (2015), besides the deforestation of the area that changes the habitat of animals, reservoirs of parasites of vector diseases (DE FRANCESCO A e CARNEIROM C, 2015; SILVEIRA M, 2016; SILVEIRA M, et al., 2018).

According to scholars, the construction of Hydroelectric Plants (HP) transforms the environment where they are implemented, triggering a variety of imbalances and profound environmental transformations directly related to the effects on the health and illness process of the populations inserted in these environments (FERRETE JA, et al., 2004; VILELA ML, et al., 2011; GRISOTTI M, 2016; SILVEIRA M, 2016). For Rodrigues EAS e Lima SC (2013) the relationship between the increase in ATL and the impacts of the construction of the $\mathrm{HP}$ is due to the destruction of the natural ecological niches of sandflies, which in these cases normally migrate to the home environment, which can provide shelter and a food source, with the presence of animals which can make the conditions of transmission of the disease to man more favorable.

The present work is a pioneer in the analysis of ATL-HIV coinfection in the transamazonian region, however, it presented results similar to the work of da Silveira SJS e Spencer PJ (2019) in the state of Tocantins. In the transamazonian region, of the 5795 patients registered on the SINAN platform with ATL, only 1146 were 
evaluated for HIV, totaling at least $80 \%$ that had not been evaluated in this regard. In agreement with these findings, in the work of da Silveira SJS e Spencer PJ (2019) confirmed ATL-HIV co-infection was observed in only 6 cases $(1.81 \%) ; 191$ cases $(57.70 \%)$ without co-infection and $134(40.48 \%)$ cases with this information ignored in the notifications in the seven years studied. Thus, highlighting that the problem of underreporting and underdiagnosis does not occur only in the transamazonian region. It is important to note that both Leishmaniasis and AIDS are notifiable diseases and must be notified in the Notifiable Diseases Information System (MINISTÉRIO DA SAÚDE, 2015).

The literature demonstrates the growing number of associations between diseases in Brazil and worldwide. The epidemiological impact of co-infection is so significant that WHO is considering introducing leishmaniasis as an AIDS-indicating disease. In this context, the need to perform the co-infection diagnosis is imperative, as its diagnosis modifies the therapeutic approach to leishmaniasis the monitoring of adverse effects, the therapeutic response and the occurrence of recurrences (MINISTÉRIO DA SAÚDE, 2015).

Failure of HIV research in patients with ATL may affect their prognosis, as there is evidence that only treatment with Amphotericin B is effective in patients with HIV co-infection with ATL, in addition, treatment with Glucantime $\AA$, which in other patients is usually the first choice, proved to be ineffective in these patients, which makes it essential that HIV research is always carried out. Therefore, simple and possible solutions to solve the problems of underdiagnosis and underreporting would be to offer a rapid HIV test for individuals diagnosed with leishmaniasis and correctly complete the Compulsory Notification Form prepared by the Ministry of Health (MISTÉRIO DA SAÚDE, 2015; MINISTÉRIO DA SAÚDE, 2017).

Regarding the comparison of the parasitological method with the histopathological one, it was expected that there would be uniformity between the exams and that all would be positive, however, only in $75 \%$ of the respondents there was this agreement. The analysis suggests that the disagreement between parasitological and histopathological exams are different professionals taking the readings of the slides on different dates and under different preparation conditions (MINISTÉRIO DA SAÚDE, 2017).

When analyzing samples that had a discrepancy between the results, it is assumed that the parasitological exam presented greater sensitivity in comparison to the histopathological exam. Thus, it was demonstrated that professionals are more qualified in parasitological assessment. This is justified by the fact that the histopathological pattern of ATL is a granuloma that can be confused with other pathologies that present a similar pattern, such as tuberculosis, sarcoidosis, Wegener's granulomatosis and paracoccidioidomycosis (PALMEIRO M, et al., 2005).

Thus, the correct histopathological diagnosis of ATL occurs only when the amastigote form of Leishmania $s p$. is observed, which is not always possible. This is probably the reason for the high rate of false negatives in this test (MINISTÉRIO DA SAÚDE, 2017). Thus, it is of utmost importance to improve the standard of diagnosis of ATL in the transamazonian region, enabling more professionals in order to avoid measurement errors. This error can lead to several interpretations, the most obvious of which are the underreporting of cases of ATL and delay in treatment, which can cause greater damage to affected patients.

Regarding treatment, the use of other drugs to replace pentavalent antimonials for the treatment of cutaneous leishmaniasis are not responsible for the reappearance of the disease. In the municipality of Altamira, for example, in the period from January 2009 to May 2019 of the 1147 registered cases, only 53 referred to the type of recurrence. Of these cases, only 51 were related to the drugs recommended by the Ministry of Health as the first choice of treatment and 6 cases with the use of other drugs. This can be explained according to Costa MS (2014) in describing that the possible causes of recurrence are: persistence of antiLeishmania antibodies in individuals living in endemic areas of ATL, where continued exposure would cause new antigenic stimuli; Leishmania species involved; irregular treatment with low doses; host immunity.

Of the 1411 cases registered in Medicilândia, 141 were relapses, this number is not so significant, but it already shows that the treatment of leishmaniasis is not effective for some people. According to Ministry of Health, unsatisfactory treatment results may be related to drug resistance or inappropriate use of medications (MINISTÉRIO DA SAÚDE, 2017). 
In the present study, it was found that there was no positive correlation between the use of other drugs (due to the failure of treatment of cutaneous leishmaniasis) and the increase in the number of deaths. In the literature, there was no evidence of a positive correlation between the use of other drugs with death from ATL. In this sense, what has been registered are cases of death from leishmaniasis after using the medication of first choice (pentavalent antimonials). Pentavalent antimonials, although proven to be effective, have a long duration of therapy, decreased effectiveness in some cases, as well as side effects such as fatigue, myalgia, arthralgia, anorexia, nausea, vomiting and headache that can lead the patient to death due to cardiotoxicity, hepatotoxicity, nephrotoxicity (MARSDEN PD, 1985; CHAPPUIS F, et al., 2011).

\section{CONCLUSION}

American Tegumentary Leishmaniasis is a disease very present in Brazil, as observed by our results, it is endemic in the transamazonian region. No association was found between the presence of skin lesions and HIV co-infection. Although not showing positivity, all patients with leishmaniasis must be tested for HIV and health professionals must register on the notification form. The tests to diagnose leishmaniasis need to be more specific and sensitive, especially in relation to histopathology, as there was no homogeneity in this study when the quality of histopathological and parasitological tests was compared. The main contribution of this work was to identify deficiencies in the care of patients with leishmaniasis in the Transamazon region and enable accurate diagnosis, as well as instituting correct treatment.

\section{REFERENCES}

1. ARAUJO-PEREIRA T, et al. Sand fly fauna (Diptera: Psychodidae: Phlebotominae) in an area of leishmaniasis transmission in the municipality of Rio Branco, state of Acre, Brazil. Parasites \& vectors, 2014; 7(1): 360.

2. ASSIS TSM, et al. Study of implementation and direct cost estimates for diagnostic tests for human visceral leishmaniasis in an urban area in Brazil. Cadernos de Saúde Publica, 2015; 31(10): 2127-2136.

3. CHAPPUIS F, et al. High mortality among older patients treated with pentavalent antimonials for visceral leishmaniasis in East Africa and rationale for switch to liposomal amphotericin B. J Antimicrobial agents, 2011; 55(1): 455-456.

4. COSTA MS. Aspectos clínico-imunológicos da Leishmaniose Recidiva cútis (LRC) causada por leishmania Viannia Braziliensis. Dissertação (Mestrado em Biotecnologia em Saúde e Medicina Investigativa) - Fundação Oswaldo Cruz, Centro de pesquisas Gonçalo Moniz, Salvador, 2014; $106 p$.

5. DE FRANCESCO A, CARNEIROM C. Atlas dos impactos da UHE Belo Monte sobre a pesca. São Paulo: Insituto Socioambiental, 2015.

6. DE OLIVEIRA GUERRA JA, et al. Epidemiologia da leishmaniose tegumentar na Comunidade São João, Manaus, Amazonas, Brasil Epidemiology of tegumentary leishmaniasis in São João, Manaus, Amazonas, Brazil. Cad. Saúde Pública, 2006; 22(11): 2319-2327.

7. ESTUMANO JC, et al. Leishmaniose tegumentar americana: Análise epidemiológica de uma década no interior da Amazônia, Brasil/American cutaneous leishmaniasis: Epidemiological analysis of a decade in the interior of the Brazilian, Amazon. Brazilian Journal of Development, 2020; 6(6): 36311-36325.

8. FERRETE JA, et al. Lagos artificiais e os fatores condicionantes e determinantes no processo saúde-doença/Artificial lakes and conditioner/determinant factors in the helth-disease process. Caminhos de Geografia, 2004; 5(13).

9. GOMES CM, et al. Complementary exams in the diagnosis of American tegumentary leishmaniasis. Anais brasileiros de dermatologia, 2014; 89(5): 701-709.

10. GOTO H, LINDOSO JAL. Current diagnosis and treatment of cutaneous and mucocutaneous leishmaniasis. J Expert review of anti-infective therapy, 2010; 8(4): 419-433.

11. GRISOTTI M. A construção de relações de causalidade em saúde no contexto da hidrelétrica de Belo Monte. J Ambiente \& Sociedade, 2016; 19(2): 287-304.

12. LAINSON R. Ecological interactions in the transmission of the leishmaniases. Phil. Trans. R. Soc. Lond. B, 1988; 321(1207): 389-404.

13. MARINHO DS, et al. Health economic evaluations of visceral leishmaniasis treatments: a systematic review. J PLoS neglected tropical diseases, 2015; 9(2): e0003527.

14. MARSDEN PD. Pentavalent antimonials: old drugs for new diseases. Revista da Sociedade Brasileira de Medicina Tropical, 1985; 18(3): 187-198.

15. MINISTÉRIO DA SAÚDE. Manual de Vigilância da Leishmaniose Tegumentar Americana. Secretaria de Vigilância em Saúde. Brasilia: Ministério da Saúde, 2007a; 182. Available from: http://bvsms.saude.gov.br/bvs/publicacoes/manual_vigilancia_leishmaniose_2ed.pdf . Acessed in: 15 out 2020. 
16. MINISTÉRIO DA SAÚDE. Sistema de Informação de Agravos de Notificação - SINAN: dados epidemiológicos. Departamento de Vigilância Epidemiológica, Secretaria de Vigilância em Saúde. Brasília: Ministério da Saúde Brasil, 2007b. Available from: http://tabnet.datasus.gov.br/cgi/deftohtm.exe?sinannet/cnv/ltapa.def Acessed in: 15 out 2020.

17. MINISTÉRIO DA SAÚDE. Manual de recomendações para diagnóstico, tratamento e acompanhamento de pacientes com a coinfecção leishmania-HIV. Secretaria de Vigilância em Saúde. Departamento de Vigilância das Doenças Transmissíveis. Brasília: Ministério da Saúde, 2015; 106. Available from: http://bvsms.saude.gov.br/bvs/publicacoes/manual_recomendacoes_pacientes_leishmania.pdf . Acessed in: 20 dez 2020.

18. MINISTÉRIO DA SAÚDE. Manual de Vigilância da Leishmaniose Tegumentar. Secretaria de Vigilância em Saúde. Departamento de Vigilância das Doenças Transmissíveis. Brasília: Ministério da Saúde, 2017; 189. Available from: http://bvsms.saude.gov.br/bvs/publicacoes/manual_vigilancia_leishmaniose_tegumentar.pdf . Acessed in: 15 out 2020.

19. PALMEIRO M, et al. Paracoccidioidomicose-revisão da literatura. J Scientia Medica, 2005; 15(4): 274-278.

20. RANGEL EF, LAINSON R. Flebotomíneos no Brasil. Rio de Janeiro: FIOCRUZ, 2003, p.

21. RODRIGUES EAS, LIMA SC. Alterações ambientais e os riscos de transmissão da Leishmaniose Tegumentar Americana na área de influência da UHE Serra do Fação, Goiás, Brasil. J. Hygeia - Revista Brasileira de Geografia Médica e da Saúde, 2013; 9(16): 159-168.

22. SILVEIRA M. A implantação de hidrelétricas na Amazônia brasileira, impactos socioambientais e à saúde com as transformações no território: o caso da UHE de Belo Monte. Tese (Doutorado em Geografia) - Universidade de Brasília, Brasília, 2016; 212. Available from: Reposítório Institucional da UNB https://repositorio.unb.br/handle/10482/20534. Acessed in: 05 jan 2021.

23. SILVEIRA M, et al. Sustentabilidade socioambiental e a saúde nos territórios (re) construídos por projetos hidrelétricos na Amazônia: o caso de Belo Monte. J. Confins, Revue Franco-Brésilienne de Géographie / Revista Franco-Brasileira de Geografia, 2018; 37(37).

24. SILVEIRA SJS, SPENCER PJ. Perfil Clínico e Epidemiológico da Leishmaniose Tegumentar Americana no Hospital de Doenças Tropicais da Universidade Federal do Tocantins. Brazilian Journal of Development, 2019; 5(11): 2478024793.

25. TELES CBG, et al. Description of a new phlebotomine species (Diptera: Psychodidae, Phlebotominae) and new records of sand flies from the State of Acre, northern Brazil. Zootaxa, 2013; 3609(1): 85-90.

26. VILELA ML, et al. Phlebotomine fauna (Diptera: Psychodidae) and putative vectors of leishmaniases in impacted area by hydroelectric plant, state of Tocantins, Brazil. J PLoS One, 2011; 6(12): e27721.

27. VILLA TCS. Estratégias de pesquisa para o controle de doenças negligenciadas: projetos colaborativos de enfermagem em rede. Revista Latino-Americana de Enfermagem, 2009; 17(4): 437-438.

28. WORLD HEALTH ORGANIZATION. Leishmaniasis in high-burden countries: an epidemiological update based on data reported in 2014. 2016. Available from: https://www.who.int/leishmaniasis/resources/who_wer9122/en/ . Acessed in: 04 jan 2021. 